\title{
Teaching and Learning with Collections: The Library as a Site for Exploration and Inspiration
}

Martin Aurand

The library is commonly seen as a site for information seeking and directed research, yet it may also serve as a site for exploration and inspiration. The library as Wunderkammer, or a cabinet of curiosities, explored through the senses, is not a new idea, but one that is commonly lost in today's disembodied digital universe. Library architecture sometimes promotes this identity. But when libraries are mute, and librarians are focused on information competencies, how do students come to perceive the library as a site of exploration and inspiration? Carnegie Mellon University's Arts Library and Special Collections Department believes that teaching and learning with rare and unique collections-and sometimes even with circulating collections-addresses this question and has special application to the education of arts students. A number of case studies with architecture students are presented in this article.

[This article is based in part on a presentation given at the Annual Meeting of the Association of Architecture School Librarians held in New Orleans in March 2010.]

\section{Learning and the Library}

Today's libraries and librarians are deeply invested in information literacy as a concept and as a method to fulfill their responsibilities for instruction and student learning. The Association of College and Research Libraries (ACRL) defines information literacy as "... a set of abilities requiring individuals to 'recognize when information is needed and have the ability to locate, evaluate, and use effectively the needed information."'11 ACRL's Information Literacy Competency Standards for Higher Education argue that information literacy is an essential human need in the context of "rapid technological change and proliferating information resources," and helps to assure a "more informed citizenry" with the "cluster of abilities necessary to use information effectively." ${ }^{2}$ Libraries and librarians are encouraged to go forth and address this need and instruct students in information literacy competencies. Librarians have become familiar with the ACRL standards and with these arguments.

While information literacy competencies are commonly seen as cross-disciplinary, there is a parallel emphasis on competencies that are specific to individual disciplines. Arts libraries and librarians have their own competency standards-Information Competencies for Students in Design Disciplines-produced on behalf of the Art Libraries Society of North America in 2007. These standards emphasize the development of basic, intermediate, and advanced skills for students in the fields of architecture, architecture history, landscape architecture, art history, studio arts, planning, fashion, interior design, and museum studies. Librarians and teaching faculty are encouraged to systematically instruct students to execute an extensive array of discipline-specific information-seeking activities, and to master an additional array of knowledge about the organization

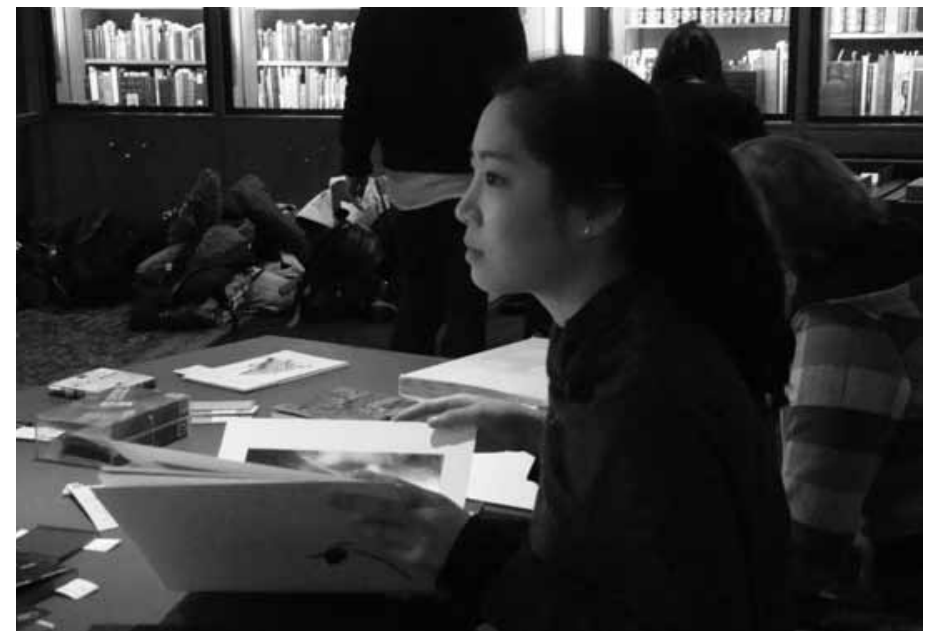

Figure 1. Class: Artists' Books. Photograph by Jillian Miller.

of information in their field. As with the ACRL standards, the competencies are rigorous and tightly focused on skill development. ${ }^{3}$ Meanwhile, archivists and special collections librarians are promoting "primary source literacy" without yet codifying competencies. ${ }^{4}$

The Carnegie Mellon University Libraries have an active Information Literacy in the Disciplines program that has been formally embraced by the university. Information literacy is one of the "new literacies" (ethics, environment, globalization, and information) cited in the university's 2008 self-study report for the Middle States Commission on Higher Education, where it is also described as one of four competencies (oral and written communication, scientific and quantitative reasoning, technological competency, and information literacy) pursued by undergraduate students at Carnegie Mellon. Information Literacy in the Disciplines programming includes the schools that make up Carnegie Mellon's College of Fine Arts. There are 
substantial activities and accomplishments to note in this area with these schools, yet information literacy is not the whole story.

According to ACRL, "information literacy forms the basis for lifelong learning. It is common to all disciplines, to all learning environments, and to all levels of education. It enables learners to master content and extend their investigations, become more self-directed, and assume greater control over their own learning. ${ }^{5}$ This language comes close to suggesting that information literacy is essential to effective learning. After participating in the ACRL Information Literacy Immersion program, Aniko Halverson refers-in the best possible way-to "the cult of information literacy." 6 This turn of phrase should perhaps cause one to wonder not so much about what information literacy has become, but what it has excluded. A broad definition of information notwithstanding, the "cult" of information literacy suggests that learning is about information seeking and directed research, and limits the role of the library to these ends. This is not wrong so much as incomplete.

Lowry Burgess, professor of art at Carnegie Mellon University, presented "Muses in the Library" as part of the 2006 Digital Libraries Colloquium Series in Pittsburgh. In the abstract for his presentation Burgess wrote, "It is my contention that as the 'cyberization' of information provides more and more disembodied information access, the physical library becomes eroticized (a place of direct social and sensory contact) and more a 'muse-eum' where the various muses dwell-those companions of Apollo, guardian of boundless human inspiration. The new library becomes a 'Wunderkammer,' a place for 'musing' and wonder, a place of direct contact and interaction with people, ideas, and multiple library objects and systems."

In the context of the colloquium series, Burgess was discussing the need to incorporate more of the intrinsic qualities of libraries into library information systems through virtual reality or other techniques. Librarians would all welcome the transformation of their largely vanilla systems, though this still seems very far away. But Burgess also casts the library as a sensory place, even more than before the digital revolution. This understanding has implications for teaching and learning in the library, especially for studio arts and architecture students who may be largely visual and tactile learners, and whose creative work may be rooted more in the senses than in information.

Burgess also says that the library "is a place to seek a broader inspiration beyond the notion of the acquisition of data or information." 8 In "Libraries \& the Inspiration Business," Brian Mathews writes, "Librarians today do more than simply organize, provide, and interpret information. We transform users' experiences, collaborating with them along their path toward self-improvement.... While building collections and providing assistance remain significant, there is definitely an evolving shift toward this more proactive role for librarians as facilitators who not only change the way patrons use content but also aim to enrich their lives. ${ }^{\prime 9}$ Matthews emphasizes the librarian's inspirational role as a facilitator of personal self-improvement, but we might also consider the inspirational aspects of teaching and learning with library collections.

\section{Library as Wunderkammer}

Burgess refers to the library as a Wunderkammer, a wonder room or cabinet of curiosities, or museum, dating from the

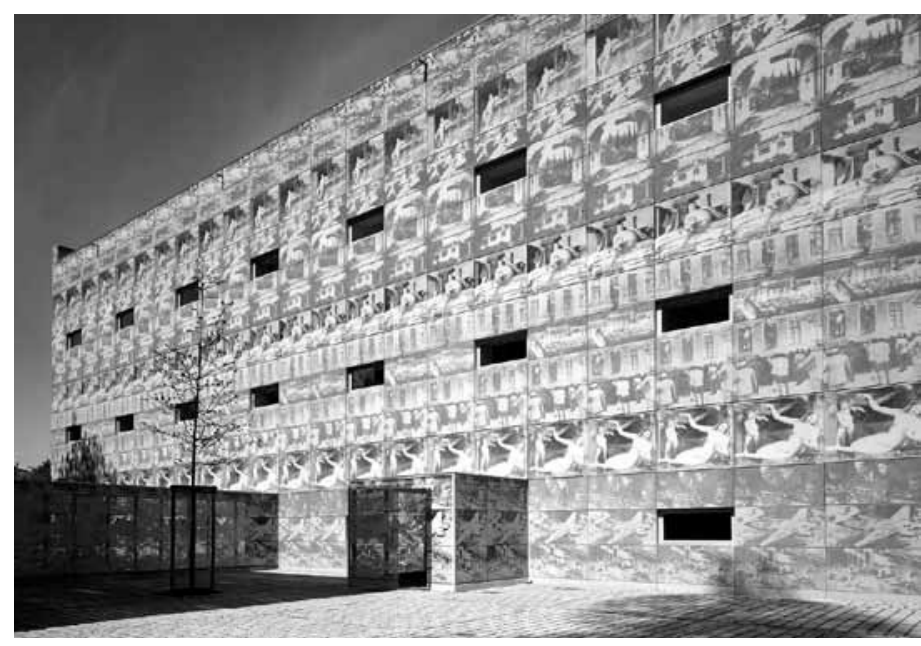

Figure 2: Herzog \& de Meuron, Eberswalde Polytechnic Library, Brandenburg, Germany, 1999. Photograph by Margherita Spiluttini. Image courtesy of Margherita Spiluttini Fotografie.

Renaissance onward, where miscellaneous books, documents, artwork, antiquities, specimens, and other natural and manmade objects were collected and given equal footing. People would explore such a collection with the senses, and select, examine, and contemplate the objects in order to develop new knowledge and insights. Burgess welcomes diverse objects and media as muses in his conception of a library, and he calls the Wunderkammer a "pre-library library." The term Wunderkammer has also been used to describe specific collections of books, and even books that are catalogs of other books or objects. The library as Wunderkammer is not a new metaphor or idea, but it is commonly lost in today's disembodied digital universe.

Library architecture sometimes promotes this identity. Library buildings frequently feature names of literary and scientific greats carved in a frieze or in some other manner on a façade, as found at the Boston Public Library designed by the prominent firm of McKim, Mead and White. According to Walter Muir Whitehill, "McKim had sought to relieve the severity of the

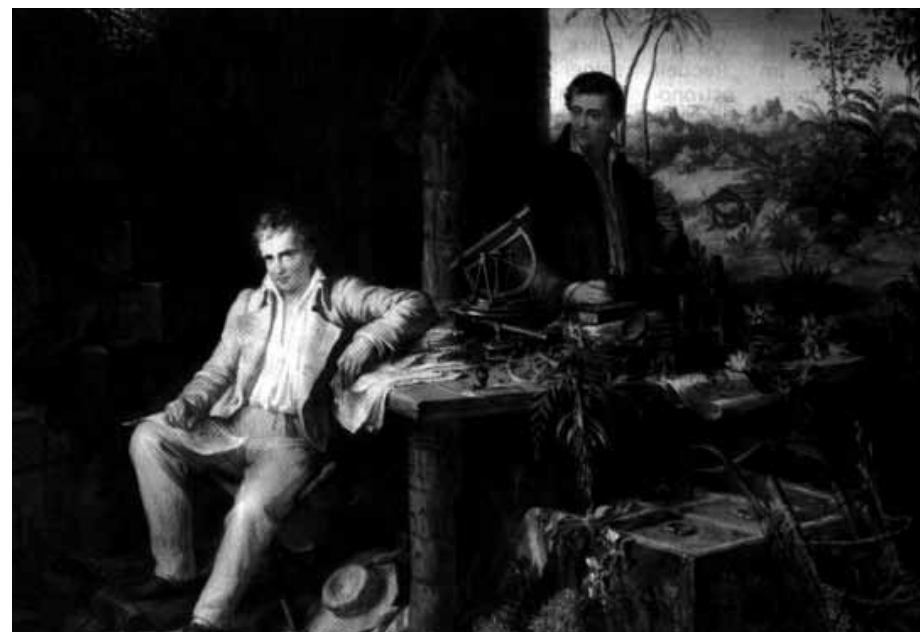

Figure 3: Eduard Ender, Alexander von Humboldt in South America with the Botanical Expert Aimé Bonpland. 1856. Image from exterior of Eberswalde Polytechnic Library, Brandenburg, Germany. Image in the public domain. 
granite façades by introducing decorative carvings and inscriptions, replete with historical and literary allusions.... [B]elow the great arched windows tablets were carved with the names of literary men, artists, scientists, statesmen, and soldiers, which served not only as a decorative relief but constituted a kind of roll of honor." These names "suggest the diversity of riches to be found within." 10

The Eberswalde Polytechnic Library in Brandenburg, Germany, designed by Herzog \& de Meuron in 1999 (Figure 2), reinvents this practice for the present age. The building itself has been compared to a "picture book."11 It is wrapped in a façade that is etched and screen-printed with provocative photographs and paintings in a way that is analogous to sgraffito or tattoo. The images promote the library as a repository of culture and science and of intellectual and visual memory. ${ }^{12}$ The specific images, as identified by Gerhard Mack, are:

- Young women on a roof garden, Berlin

- CBY-3 prototype aircraft

- Family with model railroad

- Lorenzo Lotto's Venus and Cupid

- Bernauer Strasse, Berlin on 17 June 1961 and unification celebrations

- Vanitas by Pieter Potter

- Georg Nuche, Haus am Horn, 61, Weimar

- Palazzo at Colle Ameno, Bologna

- Students in the library of the International Atlantic College, Wales

- Eduard Ender's Alexander von Humboldt in South America with the Botanical Expert Aimé Bonpland

- Stag beetle ${ }^{13}$

Mack documents the image choices and their interpretations for both the designers and the community. They tell stories of the arts and sciences, and particularly of East German society and politics. The last two save one are of particular interest for present purposes. One shows a rather antiseptic interior (which could be almost any library) with college students sitting with books and papers at long desks. The other shows Alexander von Humboldt and Aimé Bonpland with papers, scientific instruments, and botanical specimens strewn wildly about a table fashioned from trees, with the jungle creeping in (Figure 3). Alexander von Humboldt, a founding supporter of Eberswalde Polytechnic, was a famous explorer and scientist who is credited with inventing vegetational plant geography. Among his adventures he spent five years traveling in South America with botanist Aimé Bonpland. Inspired, he returned to Europe and spent twenty-eight years writing and publishing thirty volumes of Le voyage aux régions equinoxiales du Nouveau Continent, fait en 1799-1804, par Alexandre de Humboldt et Aimé Bonpland. ${ }^{14}$

The image program of the Eberswalde Library's façade describes a Wunderkammer and suggests the diversity of riches to be found within-including Humboldt's books, no doubt. The image of students studying in an antiseptic interior is countered by the image of von Humboldt and Bonpland on an adventure of exploration and inspiration. In addition, the building's few windows that have clear glazing frame and eroticize the visible contents and activity within the library. Not all library buildings are equally compelling, however. Hunt Library (Lawrie and Green, 1960), a four-story aluminum and glass box at Carnegie Mellon University, is of some interest to local fans of mid-century modern architecture, but it is inscribed with no names save the donors' (Roy and Rachel Hunt) and tells just one story. Roy Hunt was a prominent figure in the aluminum industry-hence the aluminum exterior of the building. It displays no pictures and suggests no metaphor beyond "a box of books."

How can libraries inspire students when librarians are focused on information competencies and architecture is mute? How do students learn to perceive the campus library as Wunderkammer, a wondrous and sensory place, a site for exploration and inspiration? Ultimately, of course, the library as Wunderkammer is not so much about the suggestion of diverse riches as about the collections themselves, and the people who share and explore them. Library special collections departments and archives are in the business of collecting rare books, original manuscripts, personal papers, photographs, realia, and other rare and unique materials and primary sources. Such collections are ripe with teaching and learning opportunities and are commonly marketed to humanities classes, though they may be suitable for arts classes as well. ${ }^{15}$ Art libraries also frequently feature a wide variety of intriguing collections, as documented in Jane A. Carlin's memorable article "Snow Globes, Valentines, Mail Art, Oh My!: Weird and Wonderful Art Library Collections," where the title almost says it all. ${ }^{16}$ While the possibilities are endless, artists' book collections in particular have been demonstrated to be well-suited for teaching and learning with classes of studio art, art history, and humanities students. ${ }^{17}$

\section{Teaching and Learning with Collections at Carnegie Mellon}

At Carnegie Mellon University, the Arts Library and Special Collections are combined in one department on one floor of the Hunt Library. A space that is known as the Fine and Rare Book Room, but harbors multiple collections and identities, floats in the center of the Arts Library. This room is not regularly visited by students, who may spend an academic career without entering its doors. Its outer walls hold no compelling messages, but it has sufficient glazing and interior lighting to gently eroticize the collections that are in view. Internal display cases and some very large tables can be utilized to further showcase collections. The collections are not world renowned, but they contain some gems. The room and its contents serve as a sufficient Wunderkammer.

The unusual organizational and physical configuration of the Arts Library and Special Collections Department is advantageous for teaching and learning with rare and unique collections-including rare books, artists' books, posters, architectural drawings, and music manuscripts-and even with circulating collections. The department has found a special synergy between its collections and its constituents. Classes come to the library from the schools in the College of Fine Arts (the Schools of Art, Architecture, Design, Drama, and Music), as well as from other academic departments ranging from English to Psychology. The School of Art Concept Studios for incoming freshmen are regular visitors.

Such classes commonly involve collaborative teaching. Librarians and teaching faculty contribute their expertise and insight as curators, experts, and educators in ways that reinforce and amplify course content and objectives. Students are exposed 
to carefully selected library materials that act as vehicles for exploration and inspiration.

While some of the class time may be more or less scripted, students commonly have the opportunity to explore collections at their own pace and select, examine, and contemplate books or other objects in order to develop new knowledge and insights in the spirit of the Wunderkammer. Librarians and teaching faculty circulate among the students to encourage exploration and answer questions. Some items must be displayed behind glass or on book cradles, but in such a supervised setting students are permitted to handle most materials to promote hands-on interaction and understanding.

Learning is frequently embodied in subsequent course projects that emphasize making-from writing essays to making interdisciplinary art projects. Student writers in the Beginning Poetry Workshop and art students have crafted artists' books; students in Communication Design Fundamentals have designed posters; and architecture students have built and exhibited architectural models of Le Corbusier's villas. Students may return independently to review specific items or further explore the collections. Recently an art student who had been exposed to the Artists' Books Collection returned to utilize the collection in an animated short film. The film pans from the Fine and Rare Book Room's signage and exterior to follow the path of a library cart entering the space; pans from rows of books to selected artists' books; and then enters those books to create a story arc (a love story) following characters as they jump from book to book and scenario to scenario. The library as Wunderkammer, indeed.

My librarian colleagues have taught with collections for many years, and I too have done so almost unknowingly from time to time. However, I first grasped the promise of this approach in the context of Critical Histories of the Arts, an introductory course for freshmen in the College of Fine Arts and Humanities \& Social Sciences. As architecture librarian and archivist, my subsequent experience lies largely with classes from the School of Architecture.

\section{Case Study: Rediscovering Antiquity}

The Critical Histories of the Arts course was designed to examine pluralistic histories of the arts in different regions and periods, including the classical Greek world. A teaching assistant who had been introduced to the rare book collection as a student intern invited the special collections librarian to present the university's first edition of James Stuart and Nicholas Revett's Antiquities of Athens (1762-1818) to the class. I went along to present material on the classical revival architecture of early twentieth-century Pittsburgh and the Carnegie Mellon campus.

In this case we took the volumes to a classroom, where the teaching professor set the scene. The special collections librarian displayed the Antiquities of Athens and discussed its eighteenthcentury vision and values and its role in classical studies. Students learned that Stuart and Revett, eighteenth-century British artists and architects, were the first to survey, measure, and draw the Acropolis and other key sites of ancient Athens. They visited Greece in 1751 and published their findings in four folio volumes over the next fifty years. We discussed rare books as artifacts and the publishing and graphic techniques that make the Antiquities of Athens a title of enduring value. Students were invited to examine the volumes during the class. The collab-

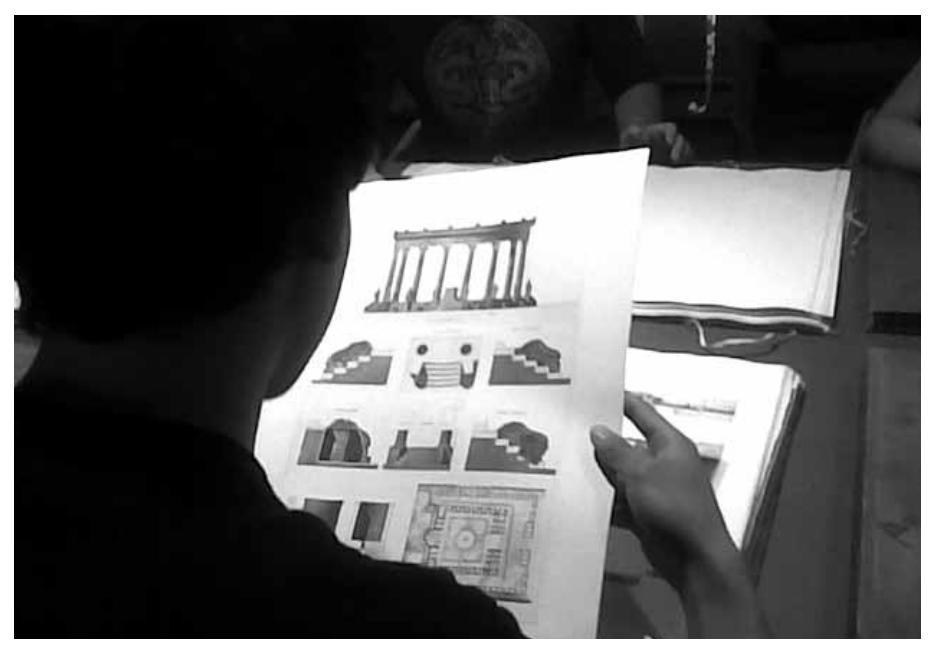

Figure 4: Class: Rediscovering Antiquity. Photograph by Martin Aurand.

orative effort between teaching faculty and librarians allowed students to explore one of the library's treasures and to learn about the persistence of classical Athens on their own campus.

Subsequently, the special collections librarian and I presented the Antiquities of Athens again for a course entitled Rediscovering Antiquity: Travelers, Archaeologists and Architects in the Mediterranean. Though it continued a theme of Critical Histories of the Arts, the latter course is a bit of an outlier in the School of Architecture. It addresses ancient cities and archaeological sites of Greece and Turkey not so much as signs of the Greek and Roman past but as objects of the late eighteenth- and nineteenthcentury era of rediscovery.

A class visit to the Fine and Rare Book Room enabled these students, if not to rediscover antiquity themselves, to explore genuine artifacts of the rediscovery, in the form of publications of the time (see the source list at the end of this article). We examined and discussed classic works by Vitruvius (1552), Vignola (16--?), and Palladio (1738), in addition to Stuart and Revett (1762-1830). Description de l'Egypte, the record of the Napoleonic expedition to Egypt (1809-1828) was a crowd pleaser. We did not show all twenty-three volumes, but the elephant folios with their extraordinary engravings took full advantage of our largest table and captivated the students with their expansiveness and their detail.

We also presented a series of lesser known works that offer descriptions and "restorations" of Mycenae (Schliemann, 1878), Olympie (Laloux, 1889), Epidaure (Lechat, 1895), and Pergame (Collignon, 1900), as well as those architecture school traditional favorites Espouy's Fragments d'architecture antique (189-?-1905) and Monuments antiques (1910). Pattern books with longwinded titles brought the story into the eighteenth and nineteenth centuries and to America. These included works by James Gibbs (1753), William Pain (1799), and John Haviland (1818-1821). The students had the opportunity to explore many of these titles on their own. They went on to create content for an interpretive project at the Hall of Architecture of the Carnegie Museum of Art, one of the world's most extraordinary collections of architectural plaster casts and a type of Wunderkammer in its own right. 


\section{Case Study: Architectural Representation}

From time to time classes come to the library to view architectural drawings from the Carnegie Mellon University Architecture Archives in the Fine and Rare Book Room. A class on campus architect Henry Hornbostel utilizes the collections extensively for their research value. Conversely, a Drawing and Media Elective course visits the Architecture Archives to expose students to a wide variety of representation methods. For an assignment called "Drawing from Precedents," the students are asked to select a specific drawing that they find engaging, and they are given the time and opportunity to study it closely. Students ultimately choose an attribute (palette, composition, quality of light, sense of space, clarity of line, etc.) and introduce it into a drawing or drawings of their own from a design project. The archival drawings and the student drawings may then be viewed side by side, creating a dialogue between the past and the present, the archives and the studio.

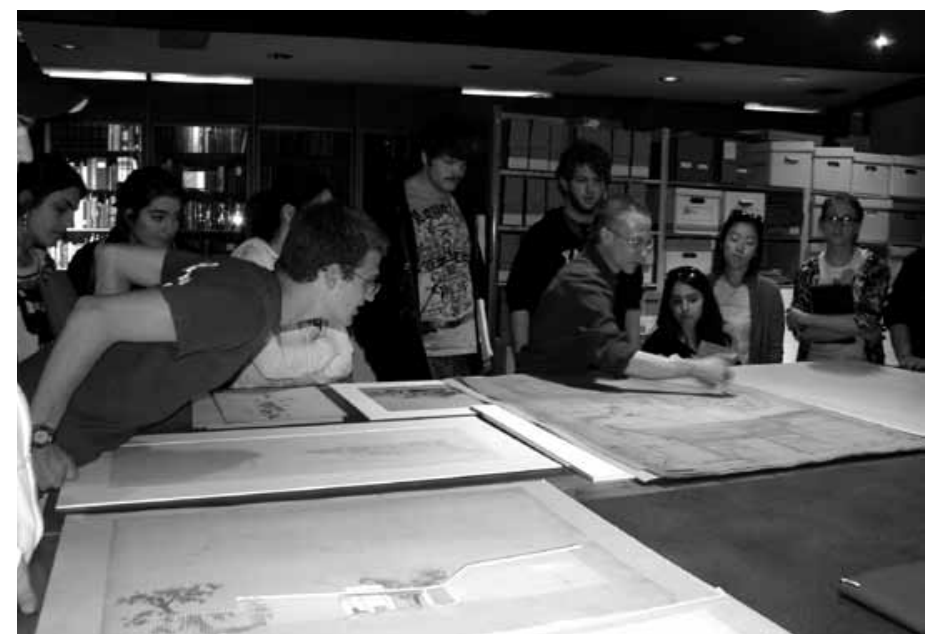

Figure 5: Class: Architectural Representation. Photograph by Jillian Miller.

First- or second-year studio classes also come to see drawing techniques to expand their knowledge of representational methods and to explore alternative directions for their own design work. We gather around a massive table built on four stacks of flat files. I present works from the Architecture Archives that range from the 1870s to the 1970s, from construction drawings to fine renderings. Media and techniques range from linen to Mylar, from pen and ink washes to pencil and colored pencil, from charcoal to pastel to watercolor. The dialogue with teaching faculty and students commonly focuses on the astonishing qualities of the drawings, historical changes in architectural practice, practical skills such as line weights, and how today's students may find their way along a spectrum of analog to digital representation techniques.

For the second-semester first-year studio, this is also an opportunity to explore selected large folio volumes and portfolios of plates (see source list). These documents present diverse examples of architectural representation, and they are frequently fine demonstrations of architectural representation in their own right. Such publications offer reproduction qualities and advantages of scale that are unrivaled in monographs and more clearly communicate lessons of technique. In a few cases they provide large-format construction drawings that are not other- wise obtainable. Varieties of technique overlap with varieties of presentation formats, from Tadao Ando's accordion-like EmakiStyle Sketchbooks (2005) to the miscellaneous parts of Daniel Libeskind and Cecil Balmond's Unfolding (1997).

Students also explore the Boxes and Folios series published in the 1980s and early 1990s by the Architectural Association in London. These extraordinary volumes demonstrate the diversity of possible approaches to a task within the constraints of a medium of presentation - which is, with few exceptions, a black box with internal dimensions of 12"x12"x.5". Each box is a designed object that contains documentation of a design project, or projects, adapted or specifically designed for this publication. Each box is a Wunderkammer.

\section{Case Study: Nolli and Le Corbusier}

In the fall of 2009, incoming first-year architecture students visited the library in studio groups for an orientation to library work, specifically focused on architecture, and a tour of the Arts Library. We do this every year, but this time the studio faculty and I had more ambitious plans.

The initial studio project focused on the campus public realm. Student groups were assigned to investigate and draw one of twenty-five quadrants of the campus in the manner of Giambattista Nolli's La pianta grande di Roma (the Nolli Map of Rome), which would ultimately be assembled into a single campus map. Students would get to know their new campus while they learned about public and private space. I visited the class and lectured on the history of the campus and its architecture to get them started. This occurred before their orientation visit and enabled the students to meet me first as a subject expert. On a subsequent visit to the library I laid out the facsimile edition of the Nolli map on our very large table. These days the Nolli map is available at the Interactive Nolli Map Web site, and the students had seen it there. However, they were mesmerized by the complexity of the facsimile in contrast to what they had seen on the screen, and what they were producing for their project. They viewed the facsimile map as if they were seeing their assignment for the first time. ${ }^{18}$

A subsequent project for the first-year students addressed fundamentals of design and representation, utilizing the villas of Le Corbusier as a vehicle. Each student was assigned a villa to

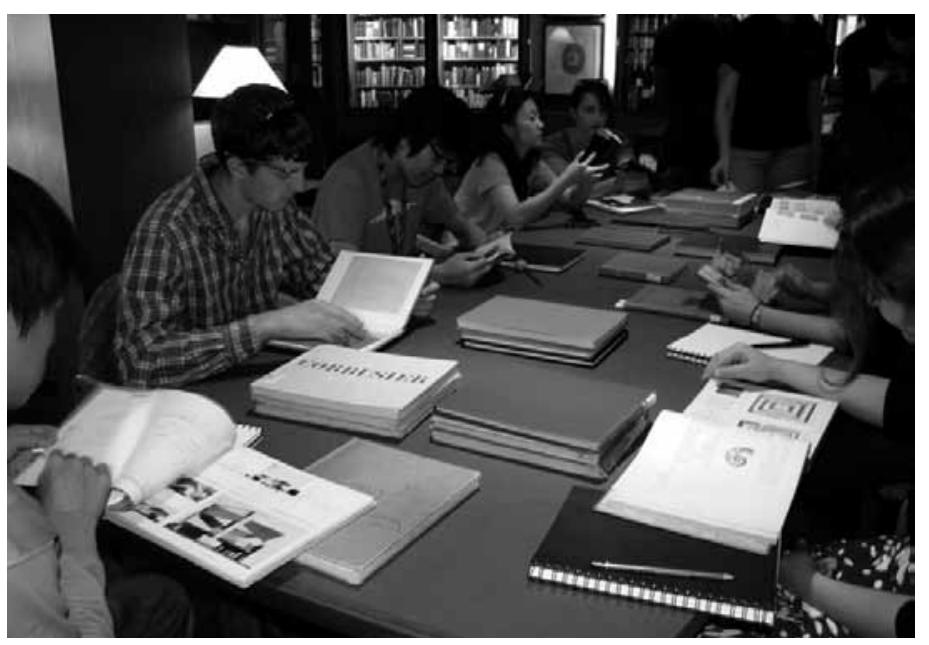

Figure 6: Class/workshop: Le Corbusier. Photograph by Jillian Miller. 
investigate. Such an assignment is not a new idea, but it was new to Carnegie Mellon where "precedent" has often been treated as a bad word. ${ }^{19}$ The students were told that they would learn the fundamentals of design and research and the conventions of graphic communication and spatial modelmaking-specifically:

- Fundamental freehand and drafting techniques

- Methods of drawing (plans, sections, elevations, axonometrics)

- The use of tracing paper

- How to use the library to obtain documentation and other information

- The understanding of architectural scale

- The role of program and its three-dimensional implications

- The organizational principles behind a design

- The graphic communication of structure, enclosure, doors, windows, etc.

- Line weight

- How to construct a study model and techniques of spatial modelmaking

- Drawing composition

- The spatial system of the building, relevant ideas of the architects, architectural terms, and a whole lot more...

Note the way that the library work is tucked in there almost randomly - to the author's mind exactly where it belongs-as a skill among skills in the broad skill set of an aspiring architect.

The library orientation session was adapted to include instruction on researching Le Corbusier villas. There was some need for articles, but books from the circulating collection, reference resources, and a few titles secured in a special location were the most useful. The last group of titles not so incidentally required the students to interact with librarians for access, especially when word got out about how useful they were. The students continued to visit the library to research their villas. Nevertheless, we planned an additional library session to keep them coming, to further convince them that there might be interesting things in the collections, to provide them with the

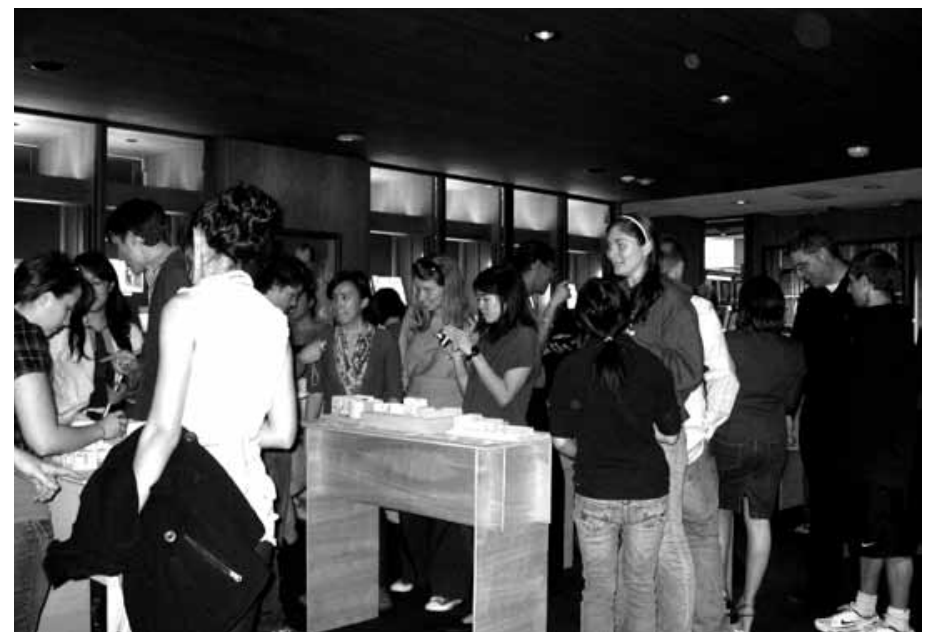

Figure 7: Exhibit/event: Le Corbusier. Photograph by Martin Aurand. opportunity to immerse themselves in the world of Le Corbusier, and to provide last-chance equal-opportunity access to key project sources that they may not have discovered on their own.

I planned an exhibit of early imprints of books written and designed by Le Corbusier. Since I was not an expert, I consulted two sources that had been recently published on Le Corbusier's books. ${ }^{20}$ The subsequent exhibit was installed in the Fine and Rare Book Room, and it was organized into an introduction and seven sections:

- Travel/Lecture Journals and Sketchbooks

- Manifestos (e.g., Vers une Architecture)

- The Modulor

- Book Art (e.g., Les plans de Paris 1956-1922)

- Synthesis (sculpture, art, design and architecture)

- Monograph (Euvre complète)

- Autobiography (Creation is a Patient Search)

When the studio groups came back to the library I walked and talked them through the exhibit, sharing what I had learned. I discovered that Le Corbusier frequently referred to himself as a "man of letters" and an "architect of books." He wrote at least thirty-five books on art, architecture, and urban planning, participated in the publication of others, and conceived many more that were never completed. Much of his creative output can be measured in publications. He utilized publications to promote his ideas and beliefs, publicize his ongoing work, and document his built and unbuilt projects. They also served as a means of self-promotion and argumentation. He provided text, graphic, and photographic content, and he frequently recycled content from one publication to another. He participated in all aspects of book design-format, paper, typeface, layout, cover design. The image of an open book often appears as a symbol or icon in his artwork and his books. Over time, his books rivaled his architectural oeuvre and revealed the evolution of his thinking as a designer.

After one student was drafted to model the Modular for the class, we turned them loose for a casual workshop of sorts. They could browse the exhibit as well as duplicates of the books that were on display, other books authored by Le Corbusier, key monographs, and key reference resources and other works relevant to their project. Some titles for the exhibit and the workshop came from the rare book or other non-circulating collections, and a few were borrowed from the professor's private collection, but many were drawn from the reference or circulating collections (see source list).

A few weeks later, when the students had completed their project work, they delivered their models of Le Corbusier's villas to the library to be displayed with the book exhibit in the Fine and Rare Book Room. This enhanced Wunderkammer became the setting for a public event on Homecoming weekend. The students were welcomed to the library for their third official visit of the semester-and they all came at once this time. The models were extremely impressive, and the students stood at the ready to discuss "their" villas with peers, faculty, and alumni. There was much taking of photographs, and photos phoned home to parents. The school was very pleased with the results.

This series of early encounters with the library was unprecedented for the incoming architecture students. They became 
comfortable in the library and familiar with the architecture librarian. They learned to explore what the library had to offer, to utilize a variety of library resources, and to perceive library collections as part of architectural study and production. Finally, they had the chance to show off some of their earliest work in a now familiar and possibly inspiring place.

\section{Conclusion}

Teaching and learning with collections provides an important complement to other library instructional programs. This practice promotes the library as Wunderkammer, and, in a sort of recursive symmetry, specific collections, books, and other library materials as Wunderkammers in their own rights. Teaching and learning with collections creates opportunities for collaboration with teaching faculty around course content, integrating student library experiences with academic work.

Rare and unique collections, though seldom the center of attention these days, are among libraries' greatest assets. ${ }^{21}$ Their content may be difficult to obtain or fully appreciate in other formats, and their artifactual qualities bring authenticity to learning. These same characteristics may be found within circulating collections as well. Today's project-focused and overwired students benefit from the opportunity to explore such collections and find inspiration for their creative work.

\section{Acknowledgments}

My thanks for collaboration and assistance to Mary Kay Johnsen, Mo Dawley, Kristin Heath, Jillian Miller, Ting Chang, Julianne Mentzer, Francesco Torello, Kai Gutschow, Diane Shaw, Kent Suhrbier, Pablo Garcia, Gerard Damiani, Catherine Essinger, and Jennifer Parker.

\section{Notes}

1. "Association of College and Research Libraries: Information Literacy Competency Standards for Higher Education," http://www.ala.org/ala/mgrps/divs/acrl/ standards/informationliteracycompetency.cfm.

2. Ibid.

3. Jeanne Brown et al., Information Competencies for Students in Design Disciplines (Calgary, Alberta: Art Libraries Society of North America, 2006, 2007), http://www.arlisna.org/pubs/ onlinepubs/informationcomp.pdf. References on information literacy and the arts library published prior to 2006 are listed in the Bibliography/Sources section of Information Competencies for Students in Design Disciplines. See also, for instance: Aniko Halverson, "Confronting Information Literacy in an Academic Arts Library," Art Documentation 27, no. 2 (Fall 2008): 34-38.

4. See, for instance, Elizabeth Yalek and Deborah Torres, "AI: Archival Intelligence and User Expertise," American Archivist 66, no. 1 (Spring/Summer 2003): 51-78; Elizabeth Yalek, "Archives and Manuscripts: Information Literacy for Primary Sources: Creating a New Paradigm for Archival Researcher Education," OCLC Systems and Services 20, no. 2 (2004), 61-64; and Joanne Archer, Ann M. Hanlon, and Jennie A. Levine, "Investigating Primary Source Literacy," The Journal of Academic Librarianship 35, no. 5 (September 2009): 410-20.

5. "ACRL: Information Literacy Competency Standards for Higher Education."
6. Halverson, "Confronting Information Literacy in an Academic Arts Library," 34.

7. Lowry Burgess, "Muses in the Library" (Digital Libraries Colloquium Series, Carnegie Mellon University, Pittsburgh, March 1, 2006), http://www.ischool.pitt.edu/colloquia/ abstract/03-01-2006.php.

8. Burgess, "Muses in the Library."

9. Brian Mathews, "Libraries \& the Inspiration Business," Library Journal 134, no. 11 (June 15, 2009): 38.

10. Walter Muir Whitehill, "The Making of an Architectural Masterpiece: The Boston Public Library," American Art Journal 2, no. 2 (Autumn 1970): 21. The architects got into some hot water by introducing an acrostic of their own names into the inscriptions.

11. Gerhard Mack, Herzog \& de Meuron: das Gesamtwerk= The Complete Works (Basel: Birkhäuser Verlag, 1996), 69.

12. Gerhard Mack and Valerie Liebermann, Eberswalde Library: Herzog \& de Meuron (London: Architectural Association, 2000), 62-63.

13. Ibid., 31-38. The images were selected by artist Thomas Ruff in association with the architects.

14. F. W. H. Alexander von Humboldt, Le voyage aux régions equinoxiales du Nouveau Continent, fait en 1799-1804, par Alexandre de Humboldt et Aimé Bonpland, 30 vols. (Paris, 18071834).

15. See, for instance, Susan M. Allen, "Rare Books and the College Library: Current Practices in Marrying Undergraduates to Special Collections," Rare Books and Manuscripts Librarianship 13, no. 2 (1999): 110-19; Ann Schmiesing and Deborah R. Hollis, "The Role of Special Collections Departments in Humanities Undergraduate and Graduate Teaching: A Case Study," portal: Libraries and the Academy 2, no. 3 (July 2002): 465-80; Meredith E. Torre, "Why Should Not They Benefit from Rare Books? Special Collections and Shaping the Learning Experience in Higher Education," Library Review 57, no. 1 (2008): 36-41; and David Pavelich, "Lighting Fires in Creative Minds: Teaching Creative Writing in Special Collections," College E Research Libraries News 71, no. 6 (June 2010): 295-97, 313.

16. Jane A. Carlin, "'Snow Globes, Valentines, Mail Art, Oh My!': Weird and Wonderful Art Library Collections," Art Documentation 18, no. 1 (Spring 1999): 46-49.

17. See, for instance, Suzy Taraba, "Now What Should We Do with Them?: Artists' Books in the Curriculum," RBM: A Journal of Rare Books, Manuscripts, and Cultural Heritage 4, no. 2 (September 21, 2003): 109-20. Teaching with artists' books was the subject of an Ask ARLIS session at the $28^{\text {th }}$ Annual Conference of the Art Libraries Society of North America: "Creative Multiples: Artists' Books as Teaching Tools" (Pittsburgh, March 20, 2000), http:/ /www.arlisna.org/news/ conferences/2000/proceedings/aa4.html.

18. Rome 1748 = Roma 1748: La pianta grande di Roma di Giambattista Nolli in facsimile, 2nd ed. (New York: J. H. Aronson, 1991); “The Interactive Nolli Map Website," http://nolli. uoregon.edu/.

19. For the results of similar investigations see Le Corbusier 1887-1965: 40 Wohnhäuser, Bauten und Projekte von Le Corbusier, Studienarbeiten an der Technischen Universität München $=40$ Houses, Buildings and Projects by Le Corbusier, Scale Models from the Technological University in Munich (Salzburg: Verlag Anton 
Pustet, 1997); Friedrich Kurrent, Raummodelle (Basel: Birkhäuser, 1999); and Ru Korubyujie no zen jutaku = Le Corbusier: Houses (Tokyo: TOTO shuppan, 2000).

20. Catherine de Smet, Le Corbusier, Architect of Books (Baden, Switzerland: Lars Müller Publishers, 2005); Le Corbusier et le livre: les livres de Le Corbusier dans leurs editions origineles $=$ las ediciones originales de los libros de Le Corbusier = Exhibition of Le Corbusier's First Edition Books = edicions originals dels llibres de Le Corbusier (Barcelona: COAC, 2005).

21. Jennifer Parker demonstrated the potential uses of rare architectural books in the academic program of a school of architecture in a presentation at the $38^{\text {th }}$ annual conference of the Art Libraries Society of North America: "Building and Promoting Unique Collections-The History of the Study \& Practice of Architecture in the U.S. at the University of Notre Dame Architecture Library" (Boston, April 24, 2010), http:// www.arlisna.org/news/conferences/2010/ses g-ppt-parker. pdf.

\section{Source lists}

\section{Rediscovering Antiquity}

Collignon, Maxime. Pergame; restauration et description des monuments de l'Acropole. Paris: Société française d'éditions d'art, 1900.

Commission des sciences et arts d'Egypte. Description de l'Egypte: ou, Recueil des observations et des recherches qui ont été faites en Egypte pendant l'expédition de l'armée française. 19 vols. in 23. Paris: Impr.impériale, 1809-1828.

Desgodets, Antoine Barbuty. Les Edifices antiques de Rome. 1682. Reprint. Farnborough: Gregg, 1969.

Espouy, H. d' (Hector d'). Fragments d'architecture antique d'après les relevés $\mathcal{E}$ restaurations des anciens pensionnaires de l'Académie de France à Rome. 2 volumes. Paris: C. Schmid, [189-?]-1905.

- Monuments antiques: relevés et restaurés par les architectes pensionnaires de l'Académie de France à Rome. Paris: C. Massin, 1910.

Laloux, Victor Alexandre Frederic. Restauration d'Olympie. Paris: Maison Quantin, 1889.

Lechat, Henri. Epidaure, restauration $\mathcal{E}$ description des principaux monuments $d u$ sanctuaire d'Asclepios. Paris: Librairieimprimeries réunies, 1895.

Palladio, Andrea. The Four Books of Andrea Palladio's Architecture, wherein, after a Short Treatise of the Five Orders, Those Observations that are Most Necessary in Building, Private Houses, Streets, Bridges, Piazzas, Xisti, and Temples are Treated Of. London: I. Ware, 1738.

Piranesi, Giovanni Battista. Oeuvres choisies de J.-B. Piranesi. Paris: A. Vincent, 1913.

Pococke, Richard. A Description of the East, and Some Other Countries. 2 vols. London: Printed for the author by W. Boyer..., 1743-1745.

Schliemann, Heinrich. Mycenae; A Narrative of Researches and Discoveries at Mycenæ and Tiryns. New York: Scribner, Armstrong \& Company, 1878.

Stuart, James, and Nicholas Revett. The Antiquities of Athens. 5 vols. London: Printed by J. Haberkorn, 1762-1830.

Vignola. Regola delli cinque ordini d'architettura. Roma: Stamparia di D. de Rossi, [16--?].
Vitruvius Pollio. De architectura libri decem ... omnibus omnium editionibus longè emendatiores, collatis veteribus exemplis. Lyon: Apvd I. Tornaesivm, 1552.

Pattern Books:

Gibbs, James. Rules for Drawing the Several Parts of Architecture, In a More Exact and Easy Manner than Has been Heretofore Practised, By Which All Fractions, In Dividing the Principal Members and Their Parts, are Avoided. London: W. Innys, 1753.

Haviland, John. The Builder's Assistant: Containing the Five Orders of Architecture, Selected from the Best Specimens of the Greek and Roman, with the Figured Dimensions of Their Height, Projection, and Profile, and a Variety of Mouldings, Modillions \& Foliage...with Working Drawings, Shewing Their Method of Construction.... 3 vols. Philadelphia: John Bioren, 1818-1821.

Pain, William. The Practical House Carpenter; Or, Youth's Instructor; Containing a Great Variety of Useful Designs in Carpentry and Architecture...To which is Added a List of Prices for Materials and Labour, Labour Only, and Day Prices. London: Printed for J. Taylor, 1799.

\section{Architectural Representation}

[Selected drawings and renderings from the Carnegie Mellon University Architecture Archives]

Architectural Association Boxes:

Eisenman, Peter. Moving Arrows, Eros and Other Errors: An Architecture of Absence. London: Architectural Association, 1986. Box 3.

Kawakami, Kisa. Plus Minus Box. London: Architectural Association, 1985. Box 2

Architectural Association Folios:

Boyarsky, Alvin. Blaubox. London: Architectural Association, 1988. Folio XIII.

Cook, Peter. 21 Years - 21 Ideas. London: Architectural Association, 1985. Folio VI.

Domenig, Günther. Steinhaus = Stonehouse. London: Architectural Association, 1986. Folio XI.

Eisenman, Peter. Fin d'Ou T Hou S. London: Architectural Association, 1985. Folio V.

Hadid, Zaha. Planetary Architecture Two. London: Architectural Association, 1983. Folio II.

Holmes, Andrew. Addition: A Folio of 20 Silkscreen Prints Which When Assembled Form a Print $1525 \times 1120 \mathrm{~mm}$. London: Architectural Association, 1986. Folio IX.

Libeskind, Daniel. Chamber Works: Architectural Meditations on Themes from Heraclitus. London: Architectural Association, 1983. Folio I.

Mozuna, Kikō. Kojiki of Architecture. London: Architectural Association, 1991. Folio XVI.

Paolozzi, Eduardo. Underground Design. London: Architectural Association, 1986. Folio X.

Purini, Franco. Around the Shadow Line: Beyond Urban Architecture. London: Architectural Association, 1984. Folio III.

Takamatsu, Shin. The Killing Moon: and Other Projects. London: Architectural Association, 1988. Folio XII.

Tschumi, Bernard. La case vide: la Villette, 1985. London: Architectural Association, 1986. Folio VIII. 
Wilson, Peter L. Bridgebuildings + The Shipshape. London: Architectural Association, 1984. Folio IV.

Wines, James. Museum of Modern Art, Frankfurt. London: Architectural Association, 1985. Folio VII.

Ando, Tadao. Tadao Ando: The Process of Creation: Emaki-Style

Sketchbooks. New York: Yoshii Gallery, 2005.

Goff, Bruce. Architecture by Bruce Goff. N.p.: Q. \& R. Blair, 1978. . Bruce Goff: A Portfolio of the Work of Bruce Goff. New

York: Architectural League of New York and the American Federation of Arts, 1970.

Kahn, Louis I. The Notebooks and Drawings of Louis I. Kahn. Cambridge, MA: MIT Press, 1973.

Libeskind, Daniel, and Cecil Balmond. Unfolding. Rotterdam: Netherlands Architecture Institute, 1997.

Mendelsohn, Erich. Eric Mendelsohn, 1887-1953. San Francisco: 1955.

Murcutt, Glenn. Glenn Murcutt, Architect. Rozelle, NSW, Australia: 01 Editions, 2006.

Museum of Modern Art. Ludwig Mies van der Rohe. New York: Museum of Modern Art, 1969.

Wright, Frank Lloyd. Buildings: Plans and Designs. New York: Horizon Press, 1963.

Nolli and Le Corbusier

Rome 1748 = Roma 1748: La pianta grande di Roma di Giambattista Nolli in facsimile, $2^{\text {nd }}$ ed. New York: J. H. Aronson, 1991.

Exhibit:

Le Corbusier. Creation is a Patient Search. New York: Praeger, 1960.

Le Corbusier. Des canons? Des munitions? Merci! Des logis ... S.V.P. ... Pavillon des temps nouveaux. Boulogne: Éditions de l'Architecture d'aujourd'hui, 1938.

Le Corbusier. L'art décoratif d'aujourd'hui. Paris: Crès, 1925.

Le Corbusier. La ville radieuse. Boulogne: Éditions de l'Architecture d'aujourd'hui, 1935.

Le Corbusier. Le modulor: essai sur une mesure harmonique à l'échelle humaine applicable universellement à l'architecture et à la mécanique. Boulogne: Éditions de l'architecture d'aujourd'hui, 1950.

Le Corbusier. Les plans de Paris 1956-1922. Paris: Éditions de Minuit, 1956.

Le Corbusier. Modulor 2, 1955 (La parole est aux usagers) Suite de «Le Modular 1948». Boulogne: Éditions de l'architecture d'aujord'hui, 1955.

Le Corbusier. Modulor Rule. New York: Princeton Architectural Press, 1990.

Le Corbusier. New World of Space. New York: Reynal \& Hitchcock, 1948.
Le Corbusier. OEuvre plastique, peintures et dessins, architecture. Paris: A. Morancé, 1938.

Le Corbusier. Précisions sur un état présent de l'architecture et de l'urbanisme. Paris: Crès, 1930.

Le Corbusier. Quand les cathédrales étaient blanches: voyage au pays des timides. Paris: Plon, 1937.

Le Corbusier. Ronchamp. Zurich: Girsberger, 1957.

Le Corbusier Sketchbooks. 4 volumes. New York: Architectural History Foundation, 1981.

Le Corbusier. Voyage d'Allemagne: carnets. Milan: Electa Architecture, 2002.

Le Corbusier. Voyage d'Orient: Sketchbooks. 6 vols. New York: Rizzoli, 1988.

Le Corbusier et Pierre Jeanneret. [OEuvre complète]. 8 vols. 1929-1970.

Le Corbusier-Saugnier. Vers une architecture. Paris: Crès, 1923.

Workshop:

Benton, Tim. The Villas of Le Corbusier and Pierre Jeanneret, 1920-1930. Rev. and exp. ed. Basel: Birkhäuser, 2007.

Cohen, Jean-Louis. Le Corbusier le grand. London: Phaidon, 2008.

Kurrent, Friedrich. Raummodelle. Basel: Birkhäuser, 1999.

Le Corbusier 1887-1965: 40 Wohnhäuser, Bauten und Projekte von Le Corbusier, Studienarbeiten an der Technischen Universität München $=40$ Houses, Buildings and Projects by Le Corbusier, Scale Models from the Technological University in Munich. Salzburg: Verlag Anton Pustet, 1997.

Le Corbusier: architecte/artiste [computer file]. London: Infinitum Publications \& Fondation Le Corbusier, 1997.

Le Corbusier Archive. 32 vols. New York: Garland, 1982-1984.

Le Corbusier. OEuvre complète. 8 vols. Basel: Birkhäuser, 2006.

Le Corbusier, une encyclopédie. Paris: Centre Georges Pompidou, 1987.

Ru Korubyujie no zen jutaku = Le Corbusier: Houses. Tokyo: TOTO shuppan, 2000.

Martin Aurand, Architecture Librarian, Archivist of the Carnegie Mellon University Architecture Archives, and Head of the Arts Library and Special Collections Department, Carnegie Mellon University, Pittsburgh, Pennsylvania, ma1f@andrew.cmu.edu 